\title{
Optogenetic strategies for the treatment of neurodegenerative diseases
}

\author{
Emel Sokullu \\ Department of Bioengineering, Faculty of Engineering and Architecture, Izmir Katip Çelebi University, Izmir, Turkey
}

\begin{abstract}
Optogenetic tools and strategies, as an innovative approach to control neurodegenerative diseases, have been developed in recent years with the application of a combination of optical and genetic techniques on a certain group of cells of living tissue. With this technique, a particular cell type and their predefined pathway can be controlled precisely. The basic steps of this optogenetics include discovery and placing of light-sensitive molecules into cells to provide optical control and applications in animal experiments. Strategies for suppressing neurons are based on activation of light-sensitive prokaryotic membrane proteins that act as ion channels and transporters. Optogenetic strategies that are adapted clinically have the capacity to provide temporal, regional and cellular specific delivery in ways that no other treatment may suggest. Engineering channelrhodopsin (CR) molecule and its expression are very important in terms of optogenetic experiments. Because experiments conducted with conventional CR are not suitable for testing chronic long-term studies, there is a certain need for a controlled medium for optogenetic neurodegenerative disease experiments.
\end{abstract}

Keywords: Alzheimer's disease; neurodegenerative diseases; optogenetics; Parkinson disease

Anatomy 2015;9(3):177-181 @2015 Turkish Society of Anatomy and Clinical Anatomy (TSACA)

\section{Introduction}

Optogenetic techniques are now gaining extremely popularity in neuroscience. The main reason for this is the possibility of studying different group of neurons associated with different brain functions with optogenetics. This may not only create new perspectives for neuroscience research, but may also describe neural network pathways that are important to create potential for the realization of important discoveries.

Another important application area of optogenetics is regulating network excitability to provide treatment strategies for degenerative brain diseases such as Parkinson and Alzheimer's disease. Controlling neuronal activation emerges as an important factor in the treatment of Alzheimer's, Parkinson and other neurodegenerative diseases. In the most general use of optogenetics, molecules with a transmembrane protein allow the passage of ions through the cell membrane in certain wavelengths. Cell type and direction of movement of the ions in the membrane effect membrane potential of neurons leading to activation (depolarization) and deactiva- tion (hyperpolarization) and thus, allow control of neurons.

\section{Neuronal Activation}

Channelrhodopsin-2 (ChR2), a cation channel unnaturally and selectively expressed by algae Chlamydomonas reinhardtii, is an important application of opsin for depolarization of mammalian neurons. ${ }^{[1]}$ Sending blue light (maximum absorption wavelength of $470 \mathrm{~nm}$ ), $\mathrm{ChR} 2, \mathrm{Na}, \mathrm{H}, \mathrm{Ca} 2+$ and $\mathrm{K}$ provide a passive $\operatorname{switch}^{[2]}$ for action potential formation caused by depolarization of cell membrane. By exposure to light on ChR2, neurons show a rapid activation kinetics and light activated ion channels are fused. This interruption closes channels quickly and exposure the light by the individual action potential channels $(1 \mathrm{E} 2 \mathrm{~ms})$ allows the formation of selective stimulation on specific neuron groups. Today, the original sequences of $\mathrm{ChR} 2$ in the literature have been revealed by various modifications and different mutagenesis approaches. ${ }^{[3]}$ The original sequence of increasing expression of ChR2 development and those 
set forth in mammalian cells focus on improving the photocurrent amplitude.

Human codon optimization for improved expression of ChR2-H134 is at $40 \mathrm{~Hz}$ and is combined with substitution of histidine for arginine at codon 134. Although the expression of ChR2 has led to an increase in photocurrent amplitude level and deactivation kinetics, frequency of the light stimulation has a decelerating effect. ${ }^{[4]}$ Therefore, further studies have concentrated on the improvement of high precision frequency stimulation channelrhodopsin shows low inactivation under continuous light stimulation (33\%) while chief ChR2 shows $77 \%$, and at $25 \mathrm{~Hz}$ frequency, consistency of the action potential is evident. ${ }^{[5]}$ Similarly, the 123 position on the ChR2 allows threonine modification of glutamic acid to obtain an advanced ChR2 variant (ChR2-E123T, CHET); so for activation/deactivation, it is possible to read a reliable and consistent action potential value shown at the $200 \mathrm{~Hz}$ level. ${ }^{[6]}$ ChR2 largely increases availability of CHET, and a direct fall in action potential formation has been observed. The small photocurrent exhibit amplitude constitutes a significant limiting factor for in vivo studies. CHET sequence of threonine 159 position in the cysteine molecules created by the modification of ChR2 variants (chr2- ET / TC) is impaired in combination with CHET with high current values. ${ }^{[7]}$

Monitoring the genomes of several microbial organisms through genetic engineering has enabled the development of tools for optogenetics at red spectral region and thus channelrhodopsin different sensitive variants have been discovered. It occurs over the depth of penetration of the red light spectral region. Increased activity of wavelengths enables to penetrate to the tissue, and it is particularly preferred for in vivo studies. Red light-sensitive channelrhodopsin global algae Volvox carteri has also been isolated and named VCHR $1 .{ }^{[8]}$ Maximum excitation wavelength was determined as $70 \mathrm{~nm}$ red light ChR2 (Z550 nm compared to $470 \mathrm{~nm}$ ) for neuronal expression. Photocurrent levels are low and in cultured neurons, and to form this action potential, there is a need for long-term exposure to light. ${ }^{[8]}$ Another red light-sensitive channelrhodopsin variant is MCHR1, Mesostig viride isolated from algae. ${ }^{[9]}$ MCHR1 shows similar maximum absorption values to VCHR1. Thus, HEK293 cells exhibit faster kinetics over $25 \mathrm{~Hz}$ light stimulation and wider photocurrent values. ${ }^{[9]}$ However, no expression was observed in neurons for MCHR $1 .{ }^{[10]}$

\section{Neuronal silencing}

The first microbial opsin that inhibits neuronal activity with light-activated chloride pump is pharaonis halorhodopsin
(NpHR) naturally expressed by Halobacterium I natronomonas. ${ }^{[1]]}$ When exposed to yellow light $(570 \mathrm{~nm}$ maximum activation), $\mathrm{NpHR}$ is actively pumped into cells by neuronal membrane hyperpolarized chlorine ions, thereby suppressing action potential. ${ }^{[12]}$ However, high amounts of $\mathrm{NpHR}$ can lead to formation of aggregates upon expression of endoplasmic reticulum and this causes cellular toxicity. ${ }^{[13]}$ In this context, it enhances cellular expression to limit the formation of aggregates.

Unlike ChR2, for high expression levels of $\mathrm{NpHR}$, a serious genetic modification is needed to access wide photocurrent and effective membrane hyperpolarization. A peptide signal from the beta subunit of $\mathrm{NpHR}$ made the first mutation process in the interior of the carbon terminal rectifier potassium channel. ER-export signal and nitrogen terminal in nicotine-acetylcholine receptor from Kir2.1 have been added for enhanced NpHR (eNpHR). eNpHR exhibits aggregate formation as well as demonstrating better expression in neural culture. On the other hand, photocurrent amplitude is increased two times more. eNpHR in cell membrane is important in order to increase the orientation and migration. ${ }^{[14]}$ The sensitivity also increased at the same time interval against infrared stimulation. Measurable membrane hyperpolarization or effective inhibition of the action potential of eNpHR is highly attractive in the need for in vivo studies of the brain.

There are other groups of molecules that may inhibit neural activity by opening proton pumps under the influence of light. Those pumps actively pump chloride into the cell, although halorhodopsin pumps protons out of the cell membrane by hyperpolarization of this protein. Archaeorhodopsin-3 (Arch) was discovered in a halobacterium Halorub sodomense with a maximum absorption of $575 \mathrm{~nm}$. Codon-optimized Arch is expressed both in vivo and in vitro in neuronal cell membrane hyperpolarization and may silence neural activity. ${ }^{[15]}$ Finally, two other rhodopsin Leptoshpaeri maculans and Halobacterium $B$ from salinarum (both improved versions, $\mathrm{eB}$ ), allow neural silencing by protons in response to blue and green light. ${ }^{[15]}$

With ChR2 or its improved variants, host cells dendrites affected a satisfactory number of inhibitory interneurons. In addition, a satisfactory inhibitory effect on the expression of dendritic stable step-function opsin (SSFO) interneurons has become possible for the excitability of interneurons and for raising their physiological excitatory synaptic response to input donation. Consequently, SSFO expression in the local neural network with a single excitation light pulse intervals inhibited and normalized on balance. ${ }^{[16]}$ 
Optogenetic tools will also help to find the most effective strategy to target the most appropriate neuronal population from the pharmacological and genetic point of view. It will allow understanding details of the mechanisms to be studied. Finally, these two different strategies (of pyramidal cell activation and silencing of specific subsets of interneurons) influence the distribution of amyloid plaques, and this effect can be increased by using these technics altogether. Pyramidal cells expressing halorhodopsin can be obtained by using proton pumps.

In a hypothetical scenario, inhibitory effects of the yellow light for the cells of the neural network are probably hyperexcitable by silencing, while the simultaneous manner of interneurons synergism or upgrading is also activated. However, the effect of each opsin combination must be carefully examined and evaluated to avoid confusion in the interpretation of results.

\section{Opsin targeting and transmission of light}

To consider optogenetics as a possible treatment strategy for Alzheimer's disease, some technical requirements are important. For example, the vector must be delivered safely to the specified anatomical areas. This suitable DNA vector, the promoter and the DNA sequence of the target cell population need to be selected to ensure stable and continuous expression. Appropriate light source should be positioned outside the cell population. In addition to these, electrodes to record the activity and stimulation created through the light source must be matched to the targeted site or microchip. ${ }^{[16,17]}$

\section{Vector manipulation}

There are many available options for sending the vector experimentally in animals. At this point, the transgenic animal (mouse) is a good approach to use. With transgenic animals, ${ }^{[1,19]} \mathrm{ChR} 2$, cell specific excretion of these drugs $^{[21-23]}$ and also suitable for $\mathrm{NpHR}$ and $\mathrm{ArCh} .{ }^{[24-26]}$ However, in interneurons, the promoters or calcium binding protein is less active in specific cells while parvalbumin expression gene promoters ${ }^{[27]}$ is needed for opsin for potentially effective neural control. Promoter enhancer sequence may be added at this point to Cre/loxP expression strategy. ${ }^{[28,29]}$ Additionally, inducible Cre-expressing arrays are also available. ${ }^{[30]}$ As a result, transmission of viral vector-based transgene transfection is a very important step and will be used widely in clinical practice in the future. In fact, viral vectors based on adeno-associated virus (AAV) have been examined for safety and efficiency in Parkinson's disease studies, and positive results have been obtained. ${ }^{[31]}$
Optical stimuli (light): For the activation of the laser light source in animal models, different light sources such as arc light source are used. ${ }^{[32]}$ When animals are implanted, miniaturized dimensions are needed. ${ }^{[33]}$ LED light source collimated light in fibers can be implanted accurately to focus on a specific zone under the skin, through a hole in the skull to the brain, similar to metal electrodes used in deep brain stimulation. Due to the limited penetration of light on brain tissue in which cells express the transgene opsin, it is necessary to determine the strength of the light from the light source to be transferred between the fibers. Integration of the tissue is necessary for minimal power. All of these assumptions lead to specific approaches in calculations and experiments in vitro. On the other hand, in vivo animal experiments and calculations showed several differences in human trials. ${ }^{[34-36]}$ Wave-length increased light scattering reduced the red-sensitive opsin (eg C1V1) as a more accurate alternative to in vivo application. ${ }^{[37-40]}$ Sending light followed by the activation of opsin can be proposed as a technical improvement in human studies. Selective targeting of specific populations of the neurons in human trials have been revealed. Although the inhibitory neurons are targeting selective expression of opsin, special subsets of interneurons and the expression of human promoters are not available. ${ }^{[41]}$ Expression of cell death or damage were monitored by weekly tests to examine its effects on immunization. ${ }^{[00,41]}$ However, tissue damage is observed in the area of the implantation optrode. $^{[37]}$

In most of the earlier studies, optogenetic experiments were carried out in rodents. Optimized transgene settings and scale settings in transmitted light for human studies are required in this context. Target area of treatment in terms of optogenetics strategies for Alzheimer's disease, needs to be less invasive and include enough cortical surface, but this approach still has certain challenges, such as the need to send light from multiple points. ${ }^{[42]}$

\section{Conclusion}

Optogenetic approach is extremely appealing to provide solutions to potential Alzheimer's and other neurodegenerative disorders, is extremely attractive. Already in the experimental stage in terms of developing new strategies, there are many problems are available to be solved and there is a need for long-term controlled trials. In this context, animal studies are required as an alternative platform. Open issues to be studied include first, gene transmission, and then alternative strategies can be reviewed in the light transmission, the feedback control 
system and so on. Apart from secondary technical issues, the complexity of the neural network is stated as the biggest difficulty to provide predictability. This point requires detailed and systematic experimental studies for a number of specific neuronal populations in brain networks and interactions. Potential ionic imbalance in the brain tissue is another important issue for optogenetics studies. All these pitfalls of optogenetic techniques in the treatment of neurodegenerative diseases have led to an increase in studies, and this technique has the potential to contribute for important treatment strategies in neurodegenerative diseases.

\section{References}

1. Boyden ES, Zhang F, Bamberg E, Nagel G, Deisseroth K. Millisecond- timescale, genetically targeted optical control of neural activity. Nat Neurosci 2005;8:1263-8.

2. Nagel G, Szellas T, Huhn W, Kateriya S, Adeishvili N, Berthold P, Ollig D, Hegemann P, Bamberg E. Channelrhodopsin-2, a directly light-gated cation-selective membrane channel. Proc Natl Acad Sci U S A 2003;100:13940-5.

3. Lin JY. A user's guide to channelrhodopsin variants: features, limitations and future developments. Exp Physiol 2011;6:19-25.

4. Gradinaru V, Thompson KR, Zhang F, Mogri M, Kay K, Schneider MB, Deisseroth K. Targeting and readout strategies for fast optical neural control in vitro and in vivo. J Neurosci 2007;27: 14231-8.

5. Lin JY, Lin MZ, Steinbach P, Tsien RY. Characterization of engineered channelrhodopsin variants with improved properties and kinetics. Biophys J 2009;96:1803-14.

6. Gunaydin LA, Yizhar O, Berndt A, Sohal VS, Deisseroth K, Hegemann P. Ultrafast optogenetic control. Nat Neurosci 2010; 13:387-92.

7. Berndt A, Schoenenberger P, Mattis J, Tye KM, Deisseroth K, Hegemann P, Oertner TG. High-efficiency channelrhodopsins for fast neuronal stimulation at low light levels. Proc Natl Acad Sci USA 2011;108:7595-600.

8. Zhang F, Prigge M, Beyriere F, Tsunoda SP, Mattis J, Yizhar O, Hegemann, P, Deisseroth K. Red-shifted optogenetic excitation: a tool for fast neural control derived from Volvox carteri. Nat Neurosci 2008;11:631-3.

9. Govorunova EG, Spudich EN, Lane CE, Sineshchekov OA, Spudich JL. New channelrhodopsin with a red-shifted spectrum and rapid kinetics from Mesostigma viride. MBio 2011;2:e0011511.

10. Yizhar O, Fenno LE, Prigge M, Schneider F, Davidson TJ, O'Shea DJ, Sohal VS, Goshen I, Finkelstein J, Paz JT, Stehfest K, Fudim R, Ramakrishnan C, Huguenard JR, Hegemann P, Deisseroth K. Neocortical excitation/inhibition balance in information processing and social dysfunction. Nature 2011;477:171-8.

11. Schobert B, Lanyi JK. Halorhodopsin is a light-driven chloride pump. J Biol Chem 1982;257:10306-13.

12. Zhang F, Wang LP, Brauner M, Liewald JF, Kay K, Watzke N, Wood PG, Bamberg E, Nagel G, Gottschalk A, Deisseroth K. Multimodal fast optical interrogation of neural circuitry. Nature 2007;446:633-9.
13. Gradinaru V, Thompson KR, Zhang F, Mogri M, Kay K, Schneider MB, Deisseroth K. Targeting and readout strategies for fast optical neural control in vitro and in vivo. J Neurosci 2007;27: 14231-8.

14. Gradinaru V, Zhang F, Ramakrishnan C, Mattis J, Prakash R, Diester I, Goshen I, Thompson KR, Deisseroth K. Molecular and cellular approaches for diversifying and extending optogenetics. Cell 2010;141:154-65.

15. Chow BY, Han X, Dobry AS, Qian X, Chuong AS, Li M, Henninger MA, Belfort GM, Lin Y, Monahan PE, Boyden ES. High-performance genetically targetable optical neural silencing by light-driven proton pumps. Nature 2010;463:98-102.

16. Yamamoto K, Tanei Z, Hashimoto T, Wakabayashi T, Okuno H, Naka Y, Yizhar O, Fenno LE, Fukayama M, Bito H, Cirrito JR, Holtzman DM, Deisseroth K, Iwatsubo T. Chronic optogenetic activation augments $\mathrm{A} \beta$ pathology in a mouse model of Alzheimer disease. Cell Rep 2015;11: 859-65.

17. Maher MP, Pine J, Wright J, Tai YC. The neurochip: a new multielectrode device for stimulating and recording from cultured neurons. J Neurosci Methods 1999;87:45-56.

18. Gradinaru V, Mogri M, Thompson KR, Henderson JM, Deisseroth K. Optical deconstruction of parkinsonian neural circuitry. Science 2009;324:354-9.

19. Arenkiel BR, Peca J, Davison IG, Feliciano C, Deisseroth K, Augustine GJ, Ehlers MD, Feng G. In vivo light-induced activation of neural circuitry in transgenic mice expressing channelrhodopsin-2. Neuron 2007;54:205-18.

20. Tomita H, Sugano E, Fukazawa Y, Isago H, Sugiyama Y, Hiroi T, Ishizuka T, Mushiake H, Kato M, Hirabayashi M, Shigemoto R, Yawo H, Tamai M. Visual properties of transgenic rats harboring the channelrhodopsin-2 gene regulated by the thy-1.2 promoter. PLoS One 2009;4:e7679.

21. Wang H, Peca J, Matsuzaki M, Matsuzaki K, Noguchi J, Qiu L, Wang D, Zhang F, Boyden E, Deisseroth K, Kasai H, Hall WC, Feng G, Augustine GJ. High-speed mapping of synaptic connectivity using photostimulation in channelrhodopsin-2 transgenic mice. Proc Natl Acad Sci U S A 2007;104:8143-8.

22. Chuhma N, Tanaka KF, Hen R, Rayport S. Functional connectome of the striatal medium spiny neuron. J Neurosci 2011;31:1183-92.

23. Zhao S, Ting JT, Atallah HE, Qiu L, Tan J, Gloss B, Augustine GJ, Deisseroth K, Luo M, Graybiel AM, Feng G. Cell type-specific channelrhodopsin-2 transgenic mice for optogenetic dissection of neural circuitry function. Nat Methods 2011;8:745-52.

24. Gradinaru V, Thompson KR, Deisseroth K. eNpHR: a Natronomonas halorhodopsin enhanced for optogenetic applications. Brain Cell Biol 2008;36:129-39.

25. Han X, Chow BY, Zhou H, Klapoetke NC, Chuong A, Rajimehr R, Yang A, Baratta MV, Winkle J, Desimone R, Boyden ES. A high-light sensitivity optical neural silencer: development and application to optogenetic control of non-human primate cortex. Front Syst Neurosci 2011;5:18.

26. Sohal VS, Zhang F, Yizhar O, Deisseroth K. Parvalbumin neurons and gamma rhythms enhance cortical circuit performance. Nature 2009;459:698-702.

27. Benzekhroufa K, Liu BH, Teschemacher AG, Kasparov S. Targeting central serotonergic neurons with lentiviral vectors based on a transcriptional amplification strategy. Gene Ther 2009; 16:681-8. 
28. Zhang F, Gradinaru V, Adamantidis AR, Durand R, Airan RD, de Lecea L, L Deisseroth K. Optogenetic interrogation of neural circuits: technology for probing mammalian brain structures. Nat Protoc 2010;5:439-56.

29. Feil S, Valtcheva N, Feil R. Inducible Cre mice. Methods Mol Biol 2009;530:343-63.

30. Marks WJ Jr, Bartus RT, Siffert J, Davis CS, Lozano A, Boulis N, Vitek J, Stacy M, Turner D, Verhagen L, Bakay R, Watts R, Guthrie B, Jankovic J, Simpson R, Tagliati M, Alterman R, Stern M, Baltuch G, Starr PA, Larson PS, Ostrem JL, Nutt J, Kieburtz $\mathrm{K}$, Kordower JH, Olanow CW. Gene delivery of AAV2-neurturin for Parkinson's disease: a double-blind, randomised, controlled trial. Lancet Neurol 2010;9:1164-72.

31. Campagnola L, Wang H, Zylka MJ. Fiber-coupled light-emitting diode for localized photostimulation of neurons expressing channelrhodopsin-2. J Neurosci Methods 2008;169:27-33.

32. Bernstein JG, Han X, Henninger MA, Ko EY, Qian X, Franzesi GT, McConnell JP, Stern P, Desimone R, Boyden ES. Prosthetic systems for therapeutic optical activation and silencing of genetically-targeted neurons. Proc SPIE Int Soc Opt Eng 2008;6854: $68540 \mathrm{H}$.

33. Yaroslavsky AN, Schulze PC, Yaroslavsky IV, Schober R, Ulrich F, Schwarzmaier HJ. Optical properties of selected native and coagulated human brain tissues in vitro in the visible and near infrared spectral range. Phys Med Biol 2002;47:2059-73.

34. Aravanis AM, Wang LP, Zhang F, Meltzer LA, Mogri MZ, Schneider MB, Deisseroth K. An optical neural interface: in vivo control of rodent motor cortex with integrated fiberoptic and optogenetic technology. J Neural Eng 2007;4:S143-56.

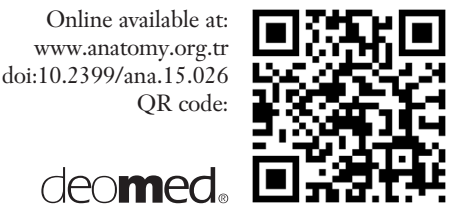

35. Huber D, Petreanu L, Ghitani N, Ranade S, Hromádka T, Mainen Z, Svoboda K. Sparse optical microstimulation in barrel cortex drives learned behaviour in freely moving mice. Nature 2008;451:61-4.

36. Yizhar O, Fenno LE, Davidson TJ, Mogri M, Deisseroth K. Optogenetics in neural systems. Neuron 2011;71:9-34.

37. Diester I, Kaufman MT, Mogri M, Pashaie R, Goo W, Yizhar O, Ramakrishnan C, Deisseroth K, Shenoy KV. An optogenetic toolbox designed for primates. Nat Neurosci 2011;14:387-97.

38. Lee JH, Durand R, Gradinaru V, Zhang F, Goshen I, Kim DS, Fenno LE, Ramakrishnan C, Deisseroth K. Global and local fMRI signals driven by neurons defined optogenetically by type and wiring. Nature 2010;465:788-92.

39. Desai M, Kahn I, Knoblich U, Bernstein J, Atallah H, Yang A, Kopell N, Buckner RL, Graybiel AM, Moore CI, Boyden ES. Mapping brain networks in awake mice using combined optical neural control and fMRI. J Neurophysiol 2011;105:1393-405.

40. Han X, Qian X, Bernstein JG, Zhou HH, Franzesi GT, Stern P, Bronson RT, Graybiel AM, Desimone R, Boyden ES. Millisecond-timescale optical control of neural dynamics in the nonhuman primate brain. Neuron 2009;62:191-8.

41. Nathanson JL, Jappelli R, Scheeff ED, Manning G, Obata K, Brenner S, Callaway EM. Short promoters in viral vectors drive selective expression in mammalian inhibitory neurons, but do not restrict activity to specific inhibitory cell-types. Front Neural Circuits 2009;3:19.

42. Maher MP, Pine J, Wright J, Tai YC. The neurochip: a new multielectrode device for stimulating and recording from cultured neurons. J Neurosci Methods 1999;87:45-56.

Correspondence to: Emel Sokullu, PhD

Department of Bioengineering, Faculty of Architecture and Engineering, Izmir Katip Çelebi University, Balatçık 35620, Çiğli, Izmir, Turkey

Phone: +905332300582

e-mail: emelsu@gmail.com

Conflict of interest statement: No conflicts declared.

This is an open access article distributed under the terms of the Creative Commons Attribution-NonCommercial-NoDerivs 3.0 Unported (CC BY-NCND3.0) Licence (http://creativecommons.org/licenses/by-nc-nd/3.0/) which permits unrestricted noncommercial use, distribution, and reproduction in any medium, provided the original work is properly cited. Please cite this article as: Sokullu E. Optogenetic strategies for the treatment of neurodegenerative diseases. Anatomy 2015;9(3):177-181. 